\title{
Field Evaluation of Soil Water Extraction of Cotton
}

\author{
José 0. Payero ${ }^{1 *}$, Graham Harris ${ }^{2}$, Geoff Robinson ${ }^{2 \#}$ \\ ${ }^{1}$ Edisto Research and Education Center, Clemson University, Blackville, USA \\ ${ }^{2}$ Department of Agriculture and Fisheries, Toowoomba, Australia \\ Email: *jpayero@clemson.edu, graham.harris@daf.qld.gov.au, geolinrobinson@bigpond.com
}

How to cite this paper: Payero, J.O., Harris, G. and Robinson, G. (2017) Field Evaluation of Soil Water Extraction of Cotton. Open Journal of Soil Science, 7, 378-400.

https://doi.org/10.4236/ojss.2017.712027

Received: September 19, 2017

Accepted: November 10, 2017

Published: December 11, 2017

Copyright () 2017 by authors and Scientific Research Publishing Inc. This work is licensed under the Creative Commons Attribution International License (CC BY 4.0).

http://creativecommons.org/licenses/by/4.0/

\begin{abstract}
Water scarcity is often a major limiting factor in cotton (Gossypium hirsutum L.) production, and sustaining productivity and profitability with limited water is a major challenge for the cotton industry. A good understanding of the magnitude, timing and spatial distribution of cotton soil water extraction is important for proper irrigation management, and for development of accurate crop models and decision support systems. The overall objective of this study was to evaluate the water extraction distribution of cotton under different irrigation regimes. Specific objectives were to quantify: 1) the depth of soil water extraction as a function of time, 2) the percent of seasonal water extraction from each soil depth, and 3) the relationship between depth of soil water extraction and canopy height. To meet these specific objectives, daily and seasonal cotton soil water extraction were determined from continuous records of water content in the soil profile measured from four irrigation treatments during a field experiment. We found that cotton extracted soil water from as deep as $150 \mathrm{~cm}$, but the percent of seasonal extraction sharply decreased with soil depth. The top $50 \mathrm{~cm}$ soil layer accounted for $75 \%$ of the seasonal extraction and the top $80 \mathrm{~cm}$, for $90 \%$. We also found that from 32 days after sowing (DAS) to $100 \mathrm{DAS}$, the depth of soil water extraction increased linearly at a rate of $1.89 \mathrm{~cm} \cdot \mathrm{day}^{-1}$ or 2.36 times the increase in crop canopy height. These findings suggest that cotton producers should manage irrigations to maintain adequate moisture in the top $80 \mathrm{~cm}$ of the soil profile rather than relying on moisture stored deeper in the profile.
\end{abstract}

\section{Keywords}

Cotton, Soil Water, Water Use, Evapotranspiration, Root Development, Effective Root Zone

${ }^{\#}$ Mr. Robinson has recently retired from the Department of Agriculture and Fisheries (DAF). 


\section{Introduction}

Water scarcity is often a major limiting factor in cotton (Gossypium hirsutum L.) production. Therefore, how to sustain or increase productivity and profitability with limited water is one of the biggest challenges facing the cotton industry in many areas of the world. This requires increasing the beneficial use of water, which implies producing more crop quantity and quality with the same amount or even less water. Some workers refer to this concept as to increase crop water productivity. According to [1], increasing crop water productivity (CWP) requires increasing transpiration while minimizing unwanted water losses, exchanging transpired water for $\mathrm{CO}_{2}$ more efficiently in producing crop biomass, and converting more of the produced biomass into harvestable yield. They also suggested that to improve CWP, the most promising and efficient proven techniques were the use of limited supplemental irrigation, to optimize the use of limited water, and the use of water harvesting, to improve farm income in drier environments.

Improving the beneficial use of water requires improving water management at different scales, including the basin, the farm and the field. At the field scale, one of the important issues includes knowing how much water to apply and when to apply it, commonly referred to as irrigation scheduling. If water is limited, then it is important to know the impact of crop stress at different times during the season, so that irrigation is applied when benefits to the crop are maximized and/or negative impacts are minimized. To be able to properly manage water under limited water situations, it is therefore important to know how crops subjected to different water regimes use soil water. Some of the relevant questions include: how much water is extracted? When is water extracted?, and from which soil depths is water extracted? A good understanding of the magnitude, timing and spatial distribution of cotton soil water extraction is important for proper irrigation management, and for development of accurate crop models and decision support systems.

Several models have been proposed to explain the growth of the effective rooting depth and the rate of extraction of soil water by the crop. For example, [2] proposed the following model to explain root zone expansion in a well-watered soil:

$$
Z=Z_{o}+\left(Z_{x}-Z_{o}\right) \sqrt[n]{\frac{\left(t-\frac{t_{o}}{2}\right)}{\left(t_{x}-\frac{t_{o}}{2}\right)}}
$$

where, $Z$ = effective rooting depth at time $t(\mathrm{~m}), Z_{o}=$ sowing depth $(\mathrm{m}), Z_{x}=$ maximum effective rooting depth $(\mathrm{m}), \mathrm{t}_{\mathrm{o}}=$ time to reach crop emergence (days or growing degree days [GDD]), $t_{x}=$ time after planting when $Z_{x}$ is reached (days or GDD), $t=$ time after planting (days or GDD), and $n=$ shape factor, which is crop-specific and determines the decreasing speed of the root zone expansion in time. They also suggested procedures to limit root expansion when 
the crop is water-stressed and for crops growing in shallow soils. This model suggests that during the expansion period, after a lag period, the growth of $Z$ may or may not be linear, depending on the crop. For cotton, they suggested values of minimum effective rooting depth $\left(Z_{n}\right)$ of $0.30 \mathrm{~m}, Z_{x}$ of up to $2.80 \mathrm{~m}, n$ $=1.5$, and root expansion rate of $1.5-2.5 \mathrm{~cm} \cdot \mathrm{d}^{-1}$. The $n \neq 1$ for cotton suggest that the increase in $Z$ for this crop is non-linear.

Also, [3] proposed combining a linear expansion of the effective rooting depth with an exponential decay function, originally described by [4] to explain the extraction of water by a crop from a given soil depth. The exponential decay function, as presented by [5] is:

$$
\theta=\theta_{l}+\theta_{a} \exp \left[-k l\left(t-t_{c}\right)\right]
$$

where, $\theta=$ volumetric soil water content $\left(\mathrm{cm}^{3} \mathrm{~cm}^{-3}\right), \theta_{1}=$ lower limit extractable water content $\left(\mathrm{cm}^{3} \cdot \mathrm{cm}^{-3}\right), \theta_{a}=$ maximum amount of water that roots can extract from surrounding soil $\left(\mathrm{cm}^{3} \cdot \mathrm{cm}^{-3}\right), k=$ constant relating to the diffusivity of water flow to and through the roots $\left(\mathrm{cm}^{2}\right.$ day $\left.^{-1}\right), l=$ root length density ( $\mathrm{cm}$ of roots per $\mathrm{cm}^{3}$ of soil), $t-t_{c}=$ duration (days) of the exponential decay, which starts in a soil layer at time $t_{c}$ The extraction rate $\left(\mathrm{cm}^{3} \cdot \mathrm{cm}^{-3} \cdot\right.$ day $\left.^{-1}\right)$ can be obtained by taking the derivative of Equation (2) with respect to time as:

$$
-\mathrm{d} \theta / \mathrm{d} t=k l \theta_{a} \exp \left(-k l\left(t-t_{c}\right)\right)=k l\left(\theta-\theta_{l}\right)
$$

Equations (2) and (3) apply for $t>t_{c}$. For $t \leq t_{c}, \theta=\theta_{a}$ and $\mathrm{d} \theta / \mathrm{d} t=0$.

This last model is commonly used in Australia [6] [7], and has been integrated into the Agricultural Production Systems Simulator (APSIM) modelling framework [8]. However, it assumes that the soil is continuously drying and does not consider the effect of rewetting the soil profile by rain or irrigation. Therefore, it is more applicable to dryland production in arid environments and might not be adequate to explain soil water dynamics in irrigated or humid environments. Both of these models rely on field experimentation to obtain crop-specific empirical parameters.

The overall objective of this study was to evaluate the water extraction distribution of cotton grown under four irrigation regimes. Specific objectives included evaluating: 1) the depth of soil water extraction as a function to time, 2) the $\%$ of seasonal water extraction from each soil depth, and 3) the relationship between depth of soil water extraction and canopy height.

\section{Methods}

\subsection{Site Description}

Data for this study were collected from a field experiment conducted during the 2007-08 cotton season at the Kingsthorpe research station of the Department of Agriculture and Fisheries. The station is located in a sub-tropical climatic zone, about $20 \mathrm{~km}$ north-west of the city of Toowoomba, Queensland, Australia $\left(27^{\circ} 30^{\prime} 44.5^{\prime \prime}\right.$ Latitude South, $151^{\circ} 46^{\prime} 54.5^{\prime \prime}$ Longitude East, $431 \mathrm{~m}$ above mean sea level). The soil at the site is a Haplic, self-mulching, black, Vertisol of alluvial fan 
and basalt rock origin, slowly permeable, and with a surface slope of about $0.5 \%$. It has a heavy clay texture in the $1.5 \mathrm{~m}$ root zone profile, with a distinct change in soil colour from brownish black in the top $90 \mathrm{~cm}$ to dark brown deeper in the profile. Physical properties of the soil profile are shown in Table 1.

\subsection{Experimental Design}

The field experiment had four irrigation treatments and three replications arranged in a randomized complete block design. Each experimental plot was 13 $\mathrm{m}$ wide $\times 20 \mathrm{~m}$ long, with the crop planted in the North-South direction. A buffer strip ( $4 \mathrm{~m}$ wide) was allowed between plots and a road ( $4 \mathrm{~m}$ wide) was located at the centre of the research area. The irrigation treatments included a fully-irrigated (T50\%), deficit-irrigated 1 (T60\%), deficit-irrigated 2 (T70\%), and deficit-irrigated 3 (T85\%) treatment, for which irrigation was applied when $50 \%$, $60 \%, 70 \%$, or $85 \%$ of the plant available water capacity (PAWC) was depleted, respectively.

\subsection{Crop Management}

The cotton hybrid Sicala 60 BRF, which is a Bollgard ${ }^{\circledR}$ II Roundup Ready Flex ${ }^{\oplus}$ variety, was planted on 12 Nov 2007, still within the Bollgard ${ }^{\circledast}$ II cotton planting window for the Darling Downs, which extended from 15 Oct to 26 Nov.Sicala 60 BRF is classified as a medium maturity variety with very good yield potential for late planting [9]. Six rows of the conventional (non-Bollgard ${ }^{\circledR}$ II) variety Sicot 43 RRF were planted as refuge crop on each of the two long sides of the experimental block. Bollgard ${ }^{\oplus}$ II cotton varieties have been developed by genetically modifying cotton by adding two genes of the soil bacterium Bacillus thuringiensis $(B t)$. The addition of these genes produces two proteins that are toxic to the $\mathrm{He}$ licoverpa caterpillar, the most important insect attacking conventional cotton varieties. Cotton was planted at a density of 17 seeds. $\mathrm{m}^{-1}$, a depth of $4 \mathrm{~cm}$ and a row spacing of $1 \mathrm{~m}$. The aim was to get an established stand of $11-12$ plants $\mathrm{m}^{-1}$.

Fertilizer applications included $188 \mathrm{~kg} \cdot \mathrm{ha}^{-1}$ of starter fertilizer $(10.5 \% \mathrm{~N}$ $19.5 \% \mathrm{P}-0 \% \mathrm{~K}-2.2 \% \mathrm{~S})$ and $126 \mathrm{~kg} \cdot \mathrm{ha}^{-1}$ of granular Urea $(46 \% \mathrm{~N})$ applied at sowing (12 Nov), and an additional $190 \mathrm{~kg} \mathrm{ha}^{-1}$ of Urea applied on $18 \mathrm{Jan}$.

Table 1. Soil physical properties at the Kingsthorpe research station.

\begin{tabular}{cccccc}
\hline $\begin{array}{c}\text { Soil Depth } \\
(\mathrm{cm})\end{array}$ & $\begin{array}{c}\text { Bulk Density } \\
\left(\mathrm{g} \cdot \mathrm{cm}^{-3}\right)\end{array}$ & $\begin{array}{c}\text { Coarse Sand } \\
(\%)\end{array}$ & $\begin{array}{c}\text { Fine Sand } \\
(\%)\end{array}$ & $\begin{array}{c}\text { Silt } \\
(\%)\end{array}$ & $\begin{array}{c}\text { Clay } \\
(\%)\end{array}$ \\
\hline $0-10$ & 0.89 & $<1$ & 8 & 17 & 76 \\
$40-50$ & 1.03 & $<1$ & 7 & 18 & 76 \\
$60-70$ & 1.05 & 2 & 8 & 19 & 72 \\
$100-110$ & 1.07 & 2 & 10 & 17 & 73 \\
$120-150$ & 1.08 & 3 & 7 & 17 & 73 \\
\hline
\end{tabular}


Weeds were controlled by a combination of manual chipping (3 Dec), mechanical cultivation (9 Jan), and a chemical control using Roundup (15 Jan). Main weeds were the Dwarf amaranth (Amaranthus macrocarpus) and Tarvine (Boerhavia dominii). The insecticide Decis (Deltamethrin) was applied on 15 March to control the Pale Cotton Stainer (Dysdercus sidae) insect.

The plots were irrigated individually with bore water using a hand-shift sprinkler system, which was fitted with partial-circle sprinkler heads to avoid irrigating adjacent plots. Irrigations were applied during times with low wind speeds to obtain adequate application uniformity. Irrigation depths were measured using a rain gauge installed at the centre of each plot. Irrigations were scheduled based on weekly measurements of soil water content from each plot using the neutron probe method.

The crop was defoliated when it reached four nodes above cracked boll (NACB). Defoliant was applied on 29 - 30 April to all treatments, except for the T50\% treatment, which had delayed maturity and received defoliant twice on 7 and 15 May. The crop was harvested on 12 - 14 May, except for the T50\% treatment, which was harvested on 22 May. The soil was then tilled twice (27 and 28 May) to comply with Pupae Busting. Pupae Busting was a requirement of the license for planting Bollgard ${ }^{\oplus}$ II cotton varieties in Australia, which mandated the full disturbance of the soil surface to a depth of $10 \mathrm{~cm}$ to prevent overwintering of the Helicoverpa.

\subsection{Measurements and Calculations}

\subsubsection{Soil Water Content}

Soil water content to schedule irrigations was measured weekly using the neutron probe method. A neutron probe access tube was installed in each plot and readings were taken at $10 \mathrm{~cm}$ depth increments to a depth of $150 \mathrm{~cm}$ with a 503DR Hydroprobe (CPN International, Inc., Martinez, CA, USA), which was calibrated for the soil at the research site against gravimetric soil moisture measurements.

Also, soil water content was automatically monitored every 30 min using EnviroSCAN• Solo (Sentek sensor technologies, Stepney, South Australia) capacitance probes installed in each treatment. This information was used to determine the depth of soil water extraction and the percent of water extraction from each soil depth. The EnviroSCAN ${ }^{\bullet}$ Solo data was used for this purpose, rather than the neutron probe data, because it provided a continuous record of soil water content in the different soil depths, which allowed a more accurate assessment of the time when soil water extraction started from each depth.

Each EnviroSCAN ${ }^{\bullet}$ Solo probe was customized to measure soil water from twelve soil depths, including 10,20,30,40,50,60,70,80,90,100, 120, and 150 $\mathrm{cm}$. According to the EnviroSCAN ${ }^{\bullet}$ Solo manufacturer, each sensor records moisture data from a soil volume outside the access tube with a sphere of influence of $10 \mathrm{~cm}$ vertical height and a radial distance from the outer wall of the access tube of $10 \mathrm{~cm}$. The probes were manually installed in the field on $14 \mathrm{Dec}$ 
2007 after the crop was established. Installation prior to this time was not possible due to frequent rainfall early in the growing season and the high risk of damaging the small cotton plants.

Prior to field installation, each of the twelve sensors in each probe was normalized by taking "air count" readings with the probe inside the PVC access tube while suspended in air, and "water count" readings with the probe in a water bath or normalization container that was constructed using an ice cooler and a piece of access tube (Figure 1). Sample air and water counts obtained are shown in Table 2.

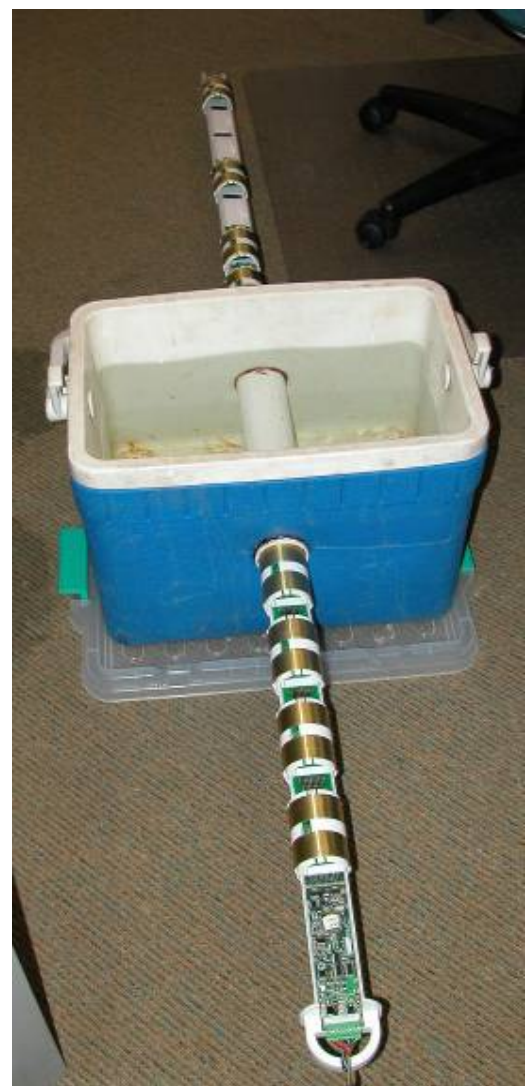

Figure 1. Normalization containing used to obtain the "water count" readings.

Table 2. Example of air and water count values obtained during the EnviroSCAN ${ }^{\circledR}$ Solo probe normalization.

\begin{tabular}{ccc}
\hline Depth $(\mathrm{cm})$ & Air Count & Water Count \\
\hline 20 & 36,797 & 26,285 \\
40 & 36,661 & 26,242 \\
60 & 37,463 & 26,712 \\
80 & 37,269 & 26,434 \\
100 & 36,686 & 26,318 \\
120 & 36,758 & 26,301 \\
\hline
\end{tabular}


The raw soil counts from each sensor were converted to volumetric soil water contents as [10]:

$$
\begin{array}{r}
S F=\frac{F a-F S}{F a-F w} \\
S F=A \theta^{B}+C \\
\theta=\left(\frac{S F-C}{A}\right)^{\frac{1}{B}}
\end{array}
$$

where, $\theta=$ volumetric soil water content $\left(\mathrm{cm}^{3} \cdot \mathrm{cm}^{-3}\right.$, or $\mathrm{mm}$ of water per $100 \mathrm{~mm}$ of soil measured), $S F=$ scaled frequencies, $F a=$ air count, $F s=$ soil count, $F W=$ water count. $S F, F a, F s$, and $F W$ are all unitless and $A, B$, and $C$ are empirical factors that depend on soil type. We used values of $A=0.0254, B=1.00$, and $C=$ 0.011 , recommended by the manufacturer for soils similar to the soil at the research site.

The EnviroSCAN ${ }^{\bullet} \mathrm{Sol} o$ data for each treatment was visually inspected to determine the time (DAS) when soil water extraction started from each depth. This point has been defined [11] as "the moment when soil water content $\left(\theta_{v}\right)$ begins to decline exponentially with time." On the other hand, [12] determined the depth of extraction from neutron probe measurements, which they called "effective rooting depth" as "the depth at which soil water content was not significantly different from the measurements made on the previous date, during a period of transpiration and in the absence of water supply", following [13].

In this study, the percent of seasonal water extraction from each soil depth was determined following these steps:

1. The daily soil water extraction for each soil depth was calculated by subtracting the current soil water content to that of the previous day.

2. The daily cumulative water use from each soil depth (cumulative depth ET) and from the whole profile (cumulative profile ET) was calculated.

3. The relative cumulative ET was calculated for each soil depth (relative cumulative EnviroSCAN ET = cumulative depth ET/cumulative profile ET).

4. For each soil depth, the fraction of seasonal water extraction (Seasonal extraction from depth/seasonal extraction from profile) was calculated.

5. For each soil depth, the cumulative fraction of seasonal water extraction was calculated.

\subsubsection{Weather Data}

Weather variables to characterize the weather conditions during the growing season were measured at the research site using an EnviroStation electronic weather station (ICT International Pty Ltd, Armidale, NSW, Australia), which recorded hourly and daily values of solar radiation $\left(R s, \mathrm{MJ} \cdot \mathrm{m}^{-2} \cdot \mathrm{d}^{-1}\right)$, air temperature $\left({ }^{\circ} \mathrm{C}\right)$ [maximum $\left(T_{\max }\right)$, minimum $\left(T_{\min }\right)$, and average $\left(T_{a}\right)$ ], relative humidity $(R H, \%)$, wind speed $\left(u, \mathrm{~m} \mathrm{~s}^{-1}\right)$ and rainfall $(\mathrm{mm})$.

The $T_{\max }$ and $T_{\min }$ data were used to calculate daily growing degree days (GDD, ${ }^{\circ} \mathrm{C}$ day), using "Method 1" of [14] as: 


$$
\mathrm{GDD}=\left[\left(T_{\max }+T_{\min }\right) / 2\right]-T_{\text {base }}
$$

Also,

$$
\text { if }\left[\left(T_{\max }+T_{\min }\right) / 2\right]<T_{\text {base }} \text {, then }\left[\left(T_{\max }+T_{\min }\right) / 2\right]=T_{\text {base }}
$$

where, $T_{\text {base }}=$ base temperature $\left({ }^{\circ} \mathrm{C}\right)$ (temperature below which no crop growth occurs). For cotton, $T_{\text {base }}=12^{\circ} \mathrm{C}$ was assumed. From the daily GDD, the cumulative GDD from sowing (CGDD, ${ }^{\circ} \mathrm{C}$-day) was then calculated. The weather data was also used to calculate the daily and monthly grass-reference evapotranspiration (ETo, mm) using the Penman-Montheith method as detailed in FAO-56 [15].

\subsubsection{Crop Development}

As an indicator of crop development, plant canopy height (h) was measured eighteen times during the season, from soon after crop emergence to defoliation. Measurements were made from four representative plants in each plot, from the soil surface to the top leaf. Also, observations about crop growth stage were recorded throughout the season.

\subsection{Data Analysis}

Statistical analysis, plotting, and calculations were conducted with the $\mathrm{R}$ language and environment for statistical computing [16].

\section{Results and Discussion}

\subsection{Weather Conditions}

Daily weather conditions during the 2007-08 cotton season at Kingsthorpe are shown in Figure 2. Daily and cumulative rainfall data are given in Figure 3 and a monthly summary of average weather variables, including daily and monthly ETo, is shown in Table 3. Higher average monthly temperatures occurred in

\begin{tabular}{|c|c|c|c|c|c|c|c|c|}
\hline \multirow[b]{2}{*}{ Variable $^{[a]}$} & \multirow[b]{2}{*}{ Nov } & \multicolumn{4}{|c|}{ Month } & \multirow[b]{2}{*}{ Apr } & \multirow[b]{2}{*}{ May } & \multirow{2}{*}{$\begin{array}{c}\text { Season } \\
\text { Avg/total }\end{array}$} \\
\hline & & Dec & Jan & Feb & Mar & & & \\
\hline $\operatorname{Tmax}\left({ }^{\circ} \mathrm{C}\right)$ & 27.0 & 29.0 & 30.7 & 29.2 & 28.0 & 25.4 & 25.0 & 27.8 \\
\hline $\operatorname{Tmin}\left({ }^{\circ} \mathrm{C}\right)$ & 14.7 & 17.5 & 17.5 & 16.1 & 12.6 & 7.3 & 3.7 & 12.8 \\
\hline $\mathrm{Rs}\left(\mathrm{MJ} \mathrm{m} \mathrm{m}^{-2} \cdot \mathrm{d}^{-1}\right)$ & 24.6 & 22.9 & 22.4 & 22.3 & 24.1 & 20.3 & 19.0 & 22.2 \\
\hline $\mathrm{RH}(\%)$ & 76.3 & 76.5 & 75.2 & 77.4 & 71.7 & 71.6 & 59.1 & 72.5 \\
\hline $\mathrm{u}\left(\mathrm{m} \cdot \mathrm{s}^{-1}\right)$ & 2.9 & 2.9 & 3.4 & 2.9 & 3.0 & 2.2 & 1.5 & 2.7 \\
\hline Daily ETo (mm) & 4.7 & 4.8 & 5.0 & 4.6 & 4.5 & 3.3 & 2.8 & 4.3 \\
\hline Monthly ETo (mm) & $88.5^{[\mathrm{b}]}$ & 149.6 & 156.1 & 132.5 & 140.5 & 100.1 & 36.7 & 804.0 \\
\hline Monthly Rain (mm) & 26.0 & 44.0 & 16.0 & 126.0 & 37.0 & 22.0 & 0.0 & 271.0 \\
\hline
\end{tabular}

Table 3. Summary weather conditions during the 2007-08 cotton season at Kingsthorpe. 


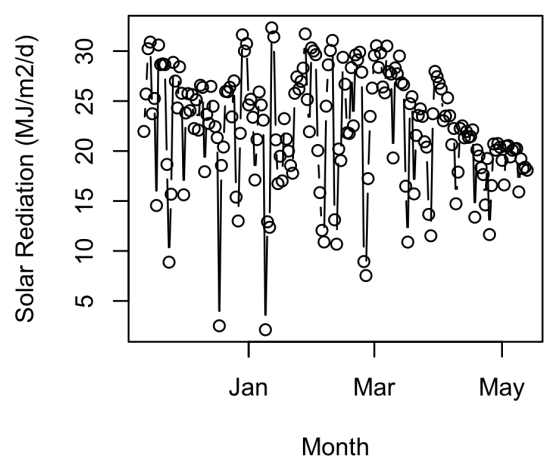

(a)

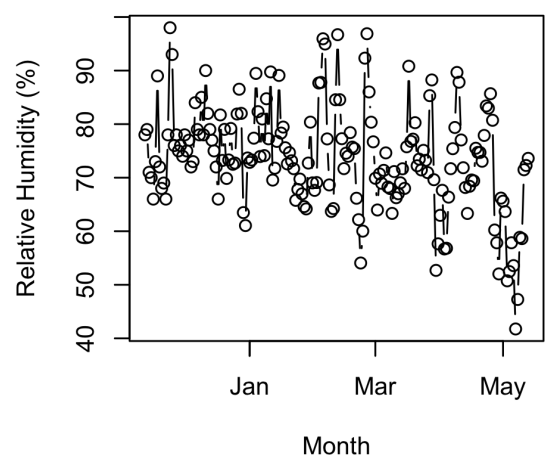

(c)

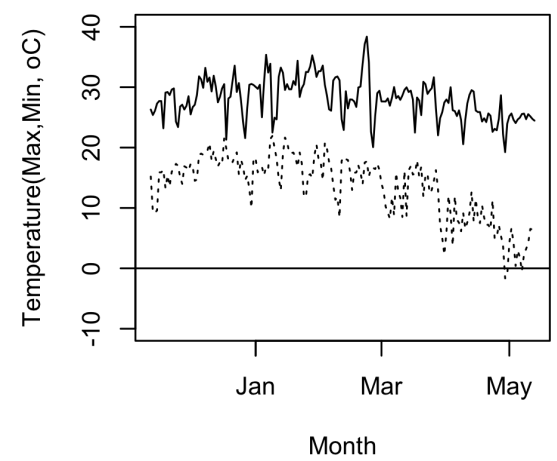

(b)

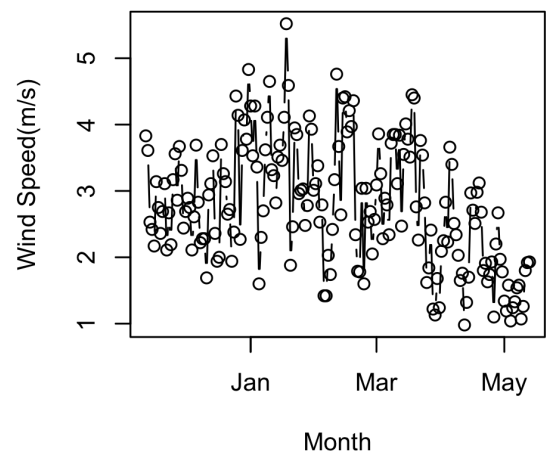

(d)

Figure 2. Averages of daily weather variables measured at Kingsthorpe during the 20072008 cotton growing season.

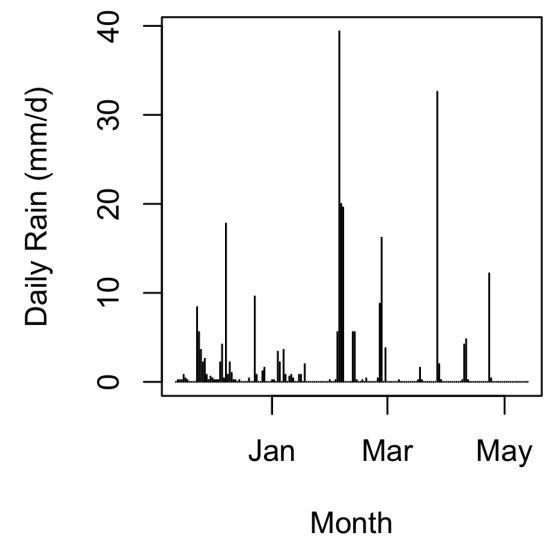

(a)

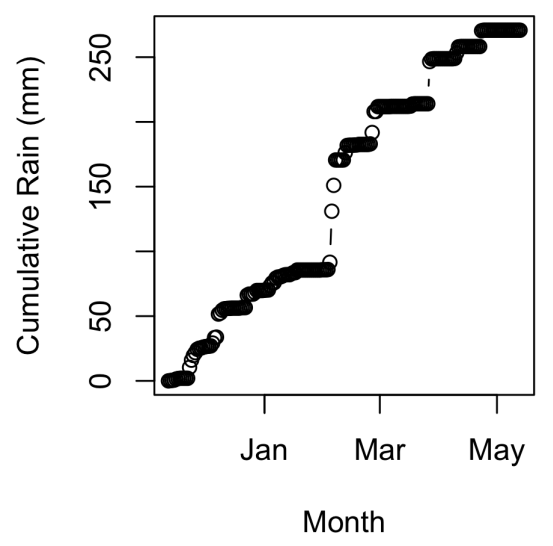

(b)

Figure 3. Daily and cumulative rain during the 2007-08 cotton growing season at Kingsthorpe.

January, which consequently also had the higher monthly ETo. Total rainfall during the growing season was $271 \mathrm{~mm}$, representing only $34 \%$ of the $804 \mathrm{~mm}$ of seasonal ETo, which explains why irrigation was needed at this site. February was the wettest month with $126 \mathrm{~mm}$ of rain, representing almost half (46\%) of the seasonal rainfall. The minimum temperature (Figure $2(b)$ ) shows that there was a frost on 29 April 2008, very late in the growing season, which visually 
stunted the crop but did not kill it. Therefore, defoliating the crop using a chemical defoliant was still needed.

Figure 4 shows the GDD and CGDD as a function of DAS. The daily GDD varied widely from day to day, ranging from 0 to $16.04^{\circ} \mathrm{C}$ day. The CGDD, however, increased smoothly as the season progressed. The increase was quite linear from sowing to $130 \mathrm{DAS}$, at a rate of $10.88^{\circ} \mathrm{C}$ day per day $\left(\mathrm{R}^{2}=0.9995\right)$. After $130 \mathrm{DAS}$, the rate decreased considerably to only $4.26^{\circ} \mathrm{C}$ day per day $\left(\mathrm{R}^{2}=\right.$ $0.96)$, as the temperature cooled down at the end of the growing season. A total of $1623^{\circ} \mathrm{C}$ days were accumulated during the 183 days from sowing to harvest.

\subsection{Irrigation}

Irrigation timing and amounts applied to each treatment are shown in Table 4. Six irrigations were applied to the wettest treatment (T50\%), ranging from 5 to $76 \mathrm{~mm}$ per irrigation event. The amount of each irrigation event was adjusted to avoid water loss by deep drainage and the application rate was low enough to prevent losses by runoff. The $\mathrm{T} 60 \%$ and $\mathrm{T} 70 \%$ treatments received practically the same amount of seasonal irrigation, but with different timing, with the T70\% receiving the first irrigation much later in the growing season. The T85\% treatment was not irrigated.

\subsection{Crop Development}

Observations about crop development stages, and their corresponding dates, DAS and CGDD, are shown in Table 5. It shows that the deficit-irrigated treatment started to mature, as indicated by the presence of open bolls, sooner than the fully-irrigated treatment. This difference in crop maturity was due to crop stress affecting the $\mathrm{T} 60 \%$, T70\% and $\mathrm{T} 85 \%$ treatments.

Crop stress also affected plant canopy height, as shown in Figure 5. Although there were not significant differences in crop canopy height early in the season, significantly differences occurred in the second half of the season due to the on-

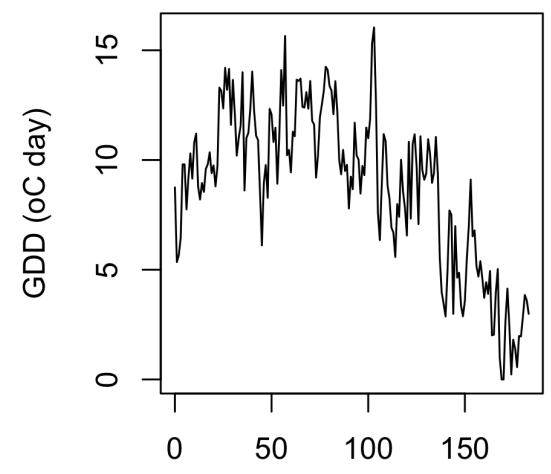

Days After Sowing

(a)

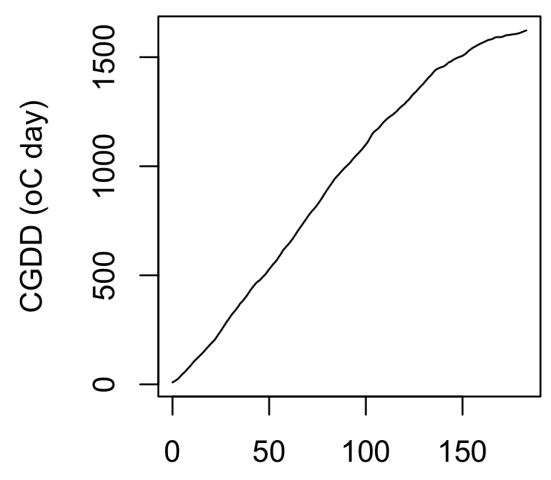

Days After Sowing

(b)

Figure 4. Growing degree-days (GDD) and cumulative GDD (CGDD) as a function of days after sowing for the 2007-08 cotton-growing season at Kingsthorpe. 
Table 4. Irrigation applied to each treatment in 2007-08 (mm).

\begin{tabular}{ccccc}
\hline & \multicolumn{4}{c}{ Irrigation Treatment } \\
\hline Date & T50\% & T60\% & T70\% & T85\% \\
\hline Jan 26, 2008 & 5 & & & \\
Jan 27, 2008 & 45 & & & \\
Jan 28, 2008 & 20 & & \\
Feb 1, 2008 & & 10 & \\
Feb 29, 2008 & 76 & 45 & \\
Mar 4, 2008 & & & & \\
Mar 27, 2008 & 58 & & & \\
Apr 21, 2008 & 24 & & $\mathbf{8 2}$ & \\
Apr 22, 2008 & & $\mathbf{8 3}$ & \\
Total & $\mathbf{2 2 8 . 0}$ & & \\
\hline
\end{tabular}

Table 5. Crop physiological stages observed for cotton at Kingsthorpe during the 2007-08 season.

\begin{tabular}{|c|c|c|c|}
\hline Date & DAS & $\begin{array}{l}\text { CGDD } \\
\left({ }^{\circ} \mathrm{C} \text {-day }\right)\end{array}$ & Crop Stage \\
\hline Nov 12, 2007 & 0 & 0 & Sowing \\
\hline Nov 20, 2007 & 8 & 73 & Emergence \\
\hline $\operatorname{Dec} 3,2007$ & 21 & 196 & 4 leaves \\
\hline Dec 10, 2007 & 28 & 286 & 6 leaves \\
\hline Dec 19, 2007 & 37 & 390 & 8 Leaves \\
\hline Jan 2, 2008 & 51 & 539 & First Square (9 nodes) \\
\hline $\operatorname{Jan} 25,2008$ & 74 & 813 & $50 \%$ Flowering \\
\hline $\operatorname{Jan} 29,2008$ & 78 & 864 & 100\% Flowering \\
\hline Jan 1, 2008 & 81 & 905 & $\begin{array}{l}\text { Crop was fully flowered and some green } \\
\text { bolls had developed }\end{array}$ \\
\hline Mar 13, 2008 & 122 & 1303 & A few open bolls in plants with severe water stress \\
\hline Apr 4, 2008 & 144 & 1480 & $\begin{array}{l}\text { A few open bolls in the fully-irrigated treatment } \\
\qquad(\mathrm{T} 50 \%)\end{array}$ \\
\hline Apr 30, 2008 & 170 & 1592 & $\begin{array}{c}\text { Defoliation of the } \mathrm{T} 60 \%, \mathrm{~T} 70 \% \text { and } \mathrm{T} 85 \% \\
\text { treatments }\end{array}$ \\
\hline May 7, 2008 & 177 & 1605 & Defoliations of the T50\% treatment \\
\hline May 14, 2008 & 184 & 1620 & Harvest \\
\hline
\end{tabular}

set of crop stress on the deficit-irrigated and dryland treatments. Significant differences started to occur in late January and early February, at about 80 DAS, when the crop was fully flowered. In general, treatments with more irrigation resulted in taller plants, with a treatment plant height ranking of $\mathrm{T} 50 \%>$ $\mathrm{T} 60 \%>\mathrm{T} 70 \%=\mathrm{T} 85 \%$. Cotton plants for the $\mathrm{T} 50 \%$ treatments were significantly 


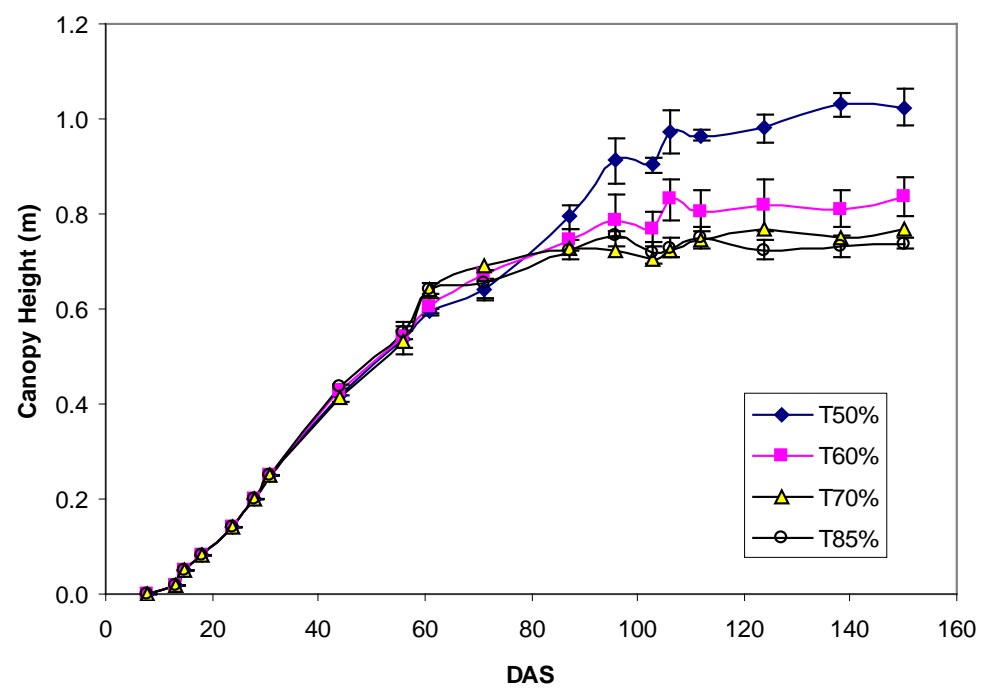

Figure 5. Plant canopy height as a function of days after sowing (DAS) for cotton grown under four irrigation treatments (T50\%, T60\%, T70\%, T85\%) at Kingsthorpe during 2007-08.

taller than the other treatments and continued to grow and to produce new bolls until the crop was defoliated. This is consistent with the fact that cotton is a perennial crop that will continue to grow as long as conditions are favourable.

\subsection{Daily Soil Water Content}

Figure 6 shows the measured daily soil water content as a function of DAS for each soil depth and treatment. There were some missing data for the T85\% treatment for a few days near the end of the season due to system malfunction. An increase in soil water content in Figure 6 indicates water input by rain, irrigation, or from redistribution of water within the soil profile due to capillary movement of water from wetter to dryer soil layers. A decrease indicates water output from the given soil depth, mainly due to soil water extraction to satisfy crop evapotranspiration, but can also be due to redistribution of water in the soil profile. In this study, increases and decreases of soil water content due to redistribution, however, were assumed to be minimal compared to the impact of rain, irrigation, and soil water extraction.

Figure 6 shows marked differences in soil water contents and water distribution in the soil profile among the four irrigation treatments. There was soil water extraction from all measurement depths down to $150 \mathrm{~cm}$, although extraction was minimal below a depth of $100 \mathrm{~cm}$. Although no soil water measurements were taken deeper than $150 \mathrm{~cm}$, there was no evidence from this study or from previous studies in similar conditions to suggest that significant amounts of water would be extracted from deeper in the soil profile. Figure 6 also shows the DAS when water started to be extracted from each depth and the relative magnitude of the water extraction. In general, as expected, changes in soil water content became less pronounced as soil depth increased. This is due to a reduction in the presence and density of roots as soil depth increases, and to a 


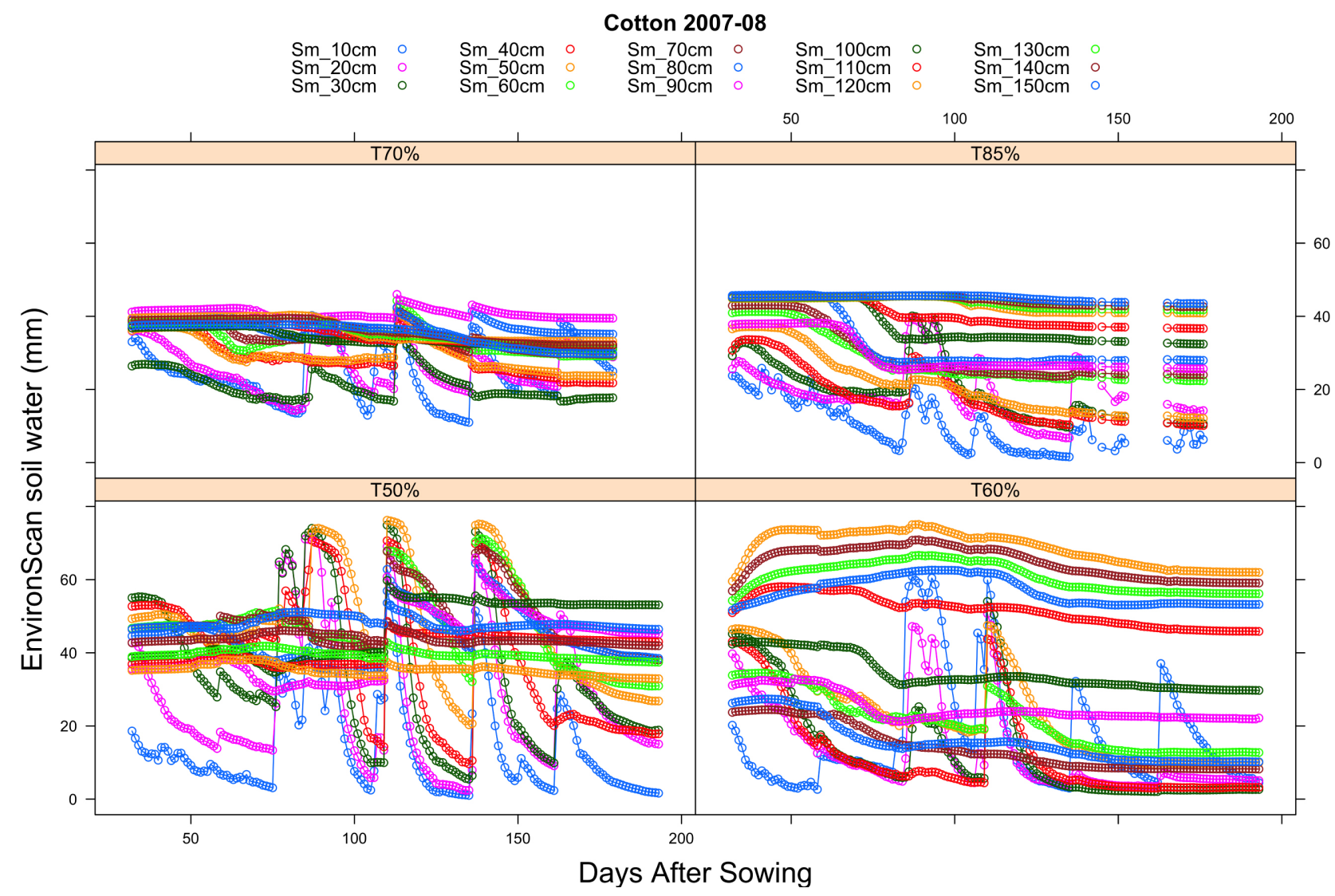

Figure 6. Daily values of soil water for different soil depths measured with EnviroScan ${ }^{\circ} o 1 o$ as a function of days after sowing for cotton grown under four irrigation treatments (T50\%, T60\%, T70\% and T85\%) at Kingsthorpe during 2007-08.Sm_10 cm, Sm_20 $\mathrm{cm}, \mathrm{Sm} \_30 \mathrm{~cm}, \ldots$ are soil moisture measured at 10,20 , and $30 \mathrm{~cm}$ depth, respectively.

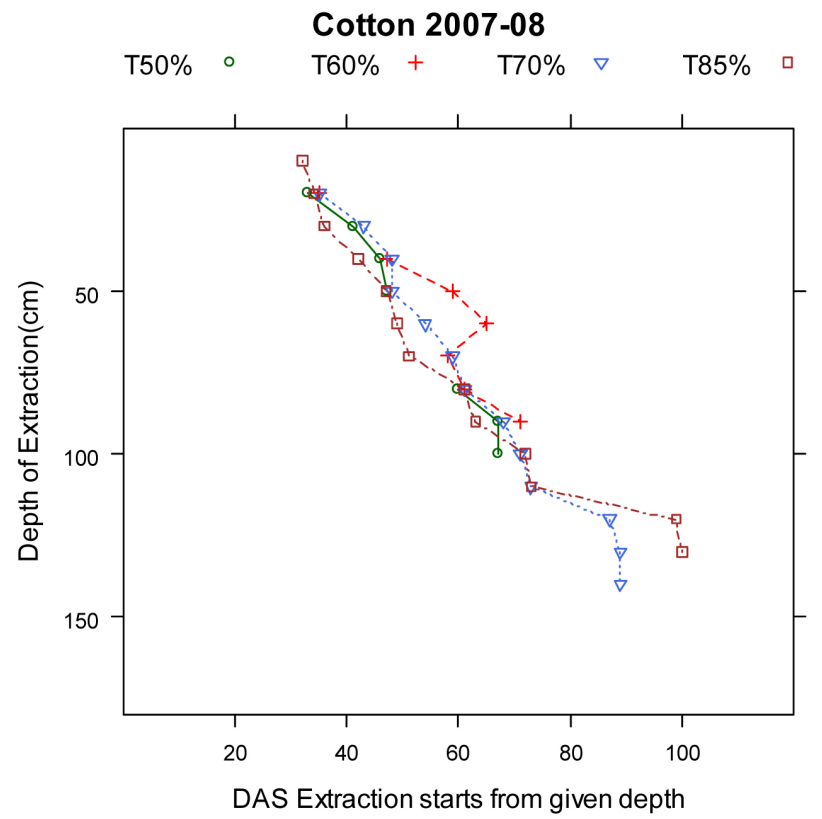

Figure 7. Depth of soil water extraction as a function of days after sowing (DAS) extraction starts from a given depth measured for cotton grown under four irrigation treatments (T50\%, T60\%, T70\% and T85\%) at Kingsthorpe during 2007-08. 
decrease in opportunity time since it takes more time for roots to reach deeper depths.

\subsection{Depth of Soil Water Extraction}

Figure 7 shows the relationship between the depth of extraction and the DAS when extraction started from a given depth for each treatment. Since depth of extraction or rooting depth cannot normally be seen in the field, it is difficult to take this variable into account with precision when scheduling irrigation. Therefore, the depth of extraction was also related to the plant canopy height (Figure 8), which can easily be measured in the field. Even though there were slight variations due to irrigation treatment, the depth of extraction tended to increase nearly linearly with both DAS extraction started from a given depth and with plant canopy height.

Figure 9(a) and Figure 9(b) shows linear regression analyses for the relationships between depth of soil water extraction as functions of DAS and CGDD extraction starts from a given depth pooling together data from all treatments. The linear relationships, however, only apply within the range of available data points, including the depth of extraction between 10 and $140 \mathrm{~cm}$. Because Envi$\operatorname{roSCAN}^{\bullet}$ Sol $o$ data was only available after $32 \mathrm{DAS}$, there was no data to characterise the relationships earlier in the season. However, it is not expected that the linear relationships will apply earlier in the season. Figure 9(a) shows that on average for all treatments the depth of extraction increased at a rate of 1.89 $\mathrm{cm} \cdot$ day $^{-1}$ from 32 DAS to about 100 DAS with no noticeable increase in depth of

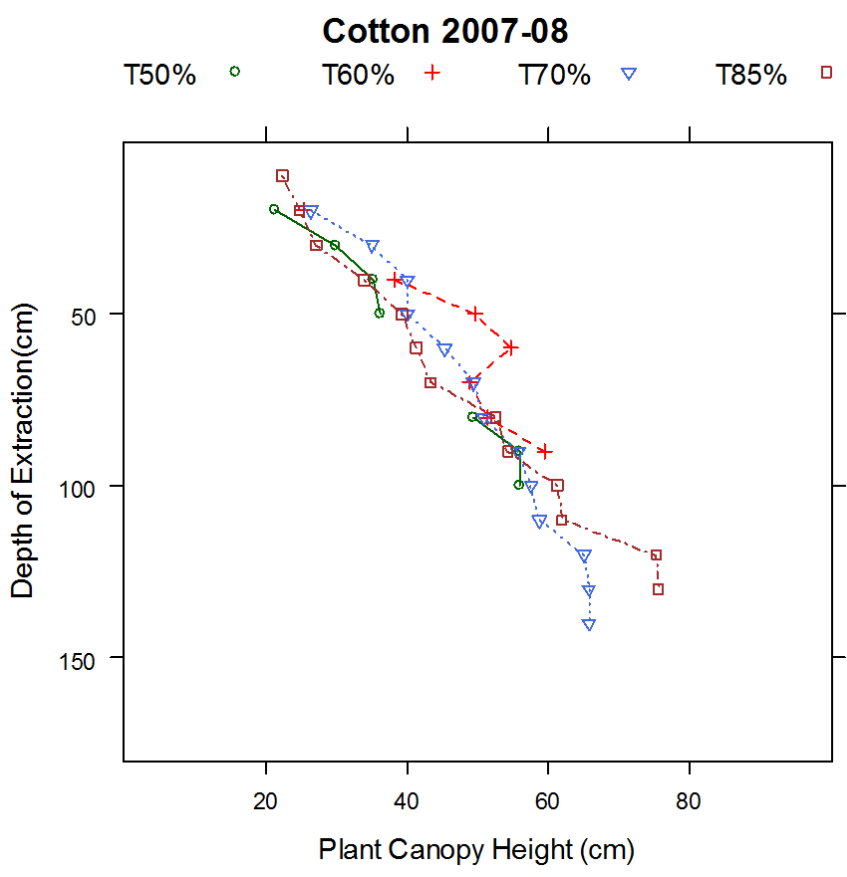

Figure 8. Depth of soil water extraction as a function of plant canopy height measured for cotton grown under four irrigation treatments (T50\%, T60\%, T70\% and $\mathrm{T} 85 \%$ ) at Kingsthorpe during 2007-08. 


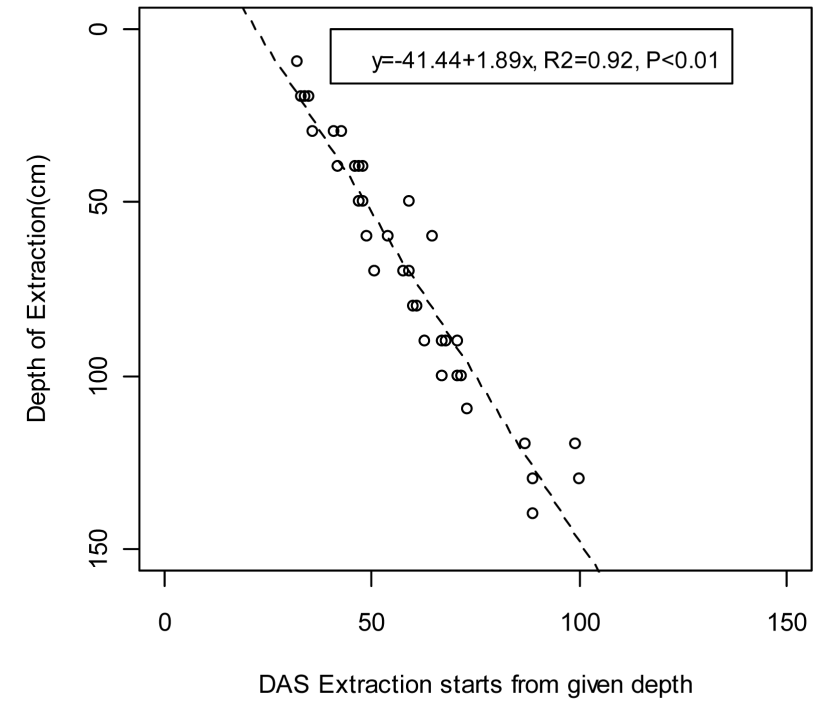

(a)

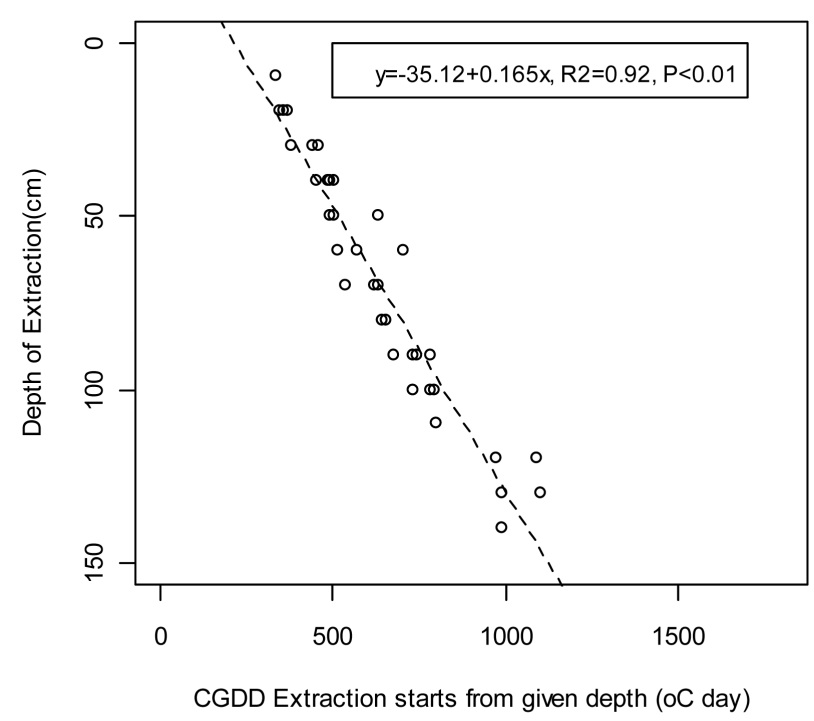

(b)

Figure 9. Depth of soil water extraction as a function of (a) days after sowing (DAS) extraction starts from a given depth and (b) cumulative growing degree days (CGDD) extraction starts from a given depth, for cotton grown at Kingsthorpe in 2007-08. Points include data from four irrigation treatments. The regression line is shown.

extraction after that time. It should be noticed that 100 DAS was also the time when plant canopy height peaked for all treatments, except the T50\% treatment which continued to increase in height after that time, but only slightly. This could suggest that at that time the crop root system also stopped growing. Extrapolation of the linear function in Figure 9(a) to the origin allows determination of the "lag period", the time it took for the depth of extraction to start increasing at the linear rate [5]. In this case the lag period was 23.5 DAS.

Figure 9 (b) also shows that the depth of extraction increased linearly with CGDD during the same time period, at an average rate of $0.165 \mathrm{~cm}$ per ${ }^{\circ} \mathrm{C}$-day. This linear relationship was expected due to the linear increase of CGDD with DAS (for DAS < 130) previously shown in Figure 4(b). The linear relationship extended from 213 to about $1000^{\circ} \mathrm{C}$-day. The depth of extraction reached its peak at the boll formation growth stage.

Figure 10 shows that the depth of extraction also increased linearly with plant canopy height. However, the depth of extraction increased much faster than the canopy height, increasing at an average rate of 2.36 times that of the crop canopy height. The linear relationship shown in Figure 10 provides an easy way for cotton growers to estimate the depth of extraction from canopy height, which is easy to measure in the field.

Other researchers have shown that the rate of increase in the depth of extraction, and the maximum depth of extraction, vary with a variety of factors, including crop species, crop variety, soil water content, and growing season. For instance, [3] reported this rate to be $1 \mathrm{~cm} \cdot \mathrm{day}^{-1}$ for rice, $2 \mathrm{~cm} \cdot \mathrm{day}^{-1}$ for barley, about $3.5 \mathrm{~cm} \cdot \mathrm{day}^{-1}$ for millet and sorghum (starting 8 days after emergence), and more than $4 \mathrm{~cm} \cdot \mathrm{day}^{-1}$ for cowpea. Also, [5] found average values of $3.4 \mathrm{~cm} \cdot \mathrm{day}^{-1}$ 


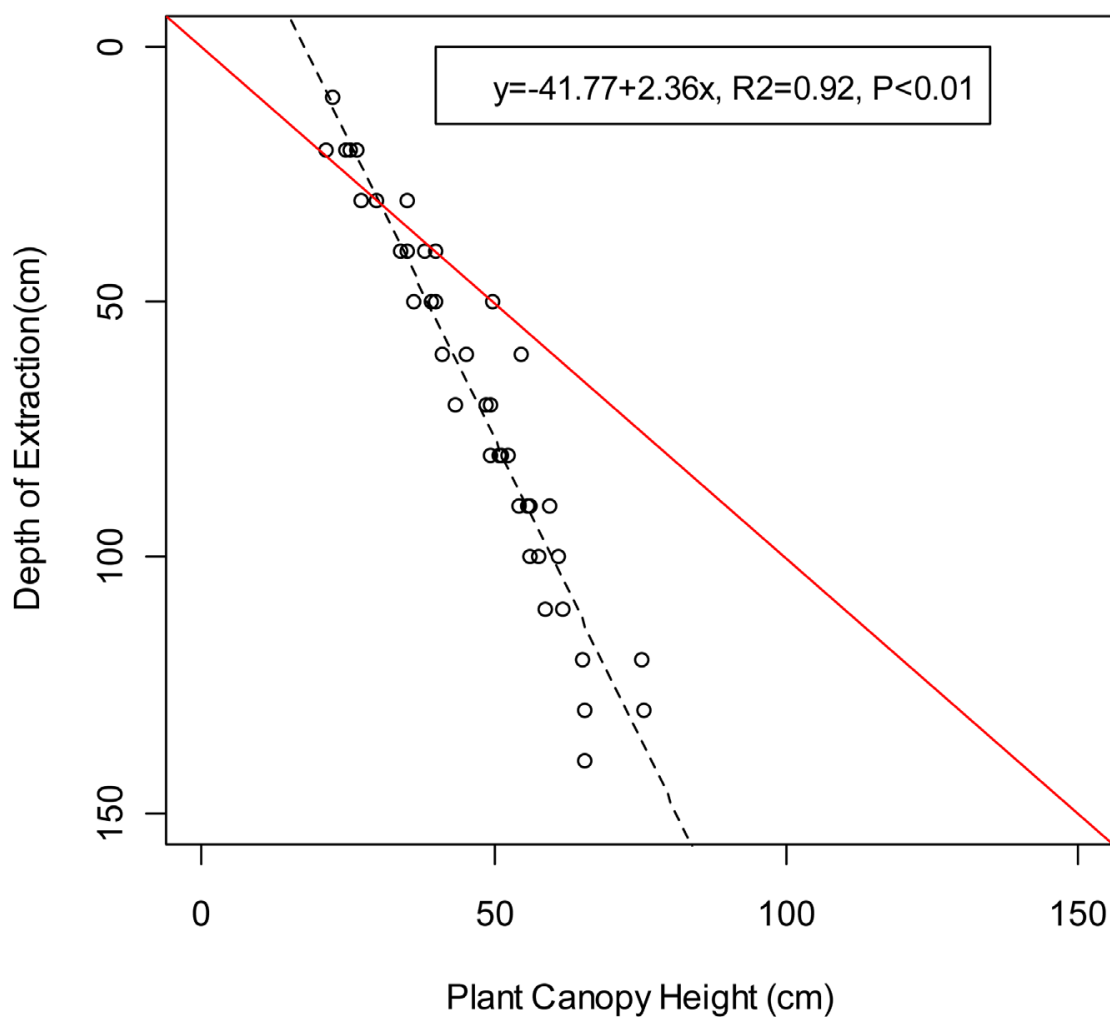

Figure 10. Depth of soil water extraction as a function plant canopy height, for cotton grown at Kingsthorpe in 2007-08. The regression (dashed) and 1:1 (solid) lines are shown. Points include data from four irrigation treatments.

for different sorghum cultivars, with values ranging from 3.27 to 4.92 among cultivars, and lag period of 14.8 - 19.3 days. Similarly, [11] found values of 4.39 $\mathrm{cm} \cdot \mathrm{day}^{-1}$ for sorghum and a lag period of 18.1 days. They also found that the depth of extraction did not exactly match the depth of the roots and that the increase in root front did not have a lag period as did the extraction front. Therefore, although the rate of increase of the root front $\left(2.72 \mathrm{~cm} \cdot \mathrm{day}^{-1}\right)$ was slower than that of the extraction front $\left(4.39 \mathrm{~cm} \cdot \mathrm{day}^{-1}\right)$ for depths of less than $120 \mathrm{~cm}$, the opposite occurred beyond that depth. These differences in the rate of increase of the depth of extraction and in the lag period could partially explain why some crops are more tolerant to water shortages than others.

For cotton, [12] found that the maximum depth of extraction (called maximum effective rooting depth $\left[\mathrm{ERD}_{\max }\right]$ ) was close to the depth of soil hydration, which depends on the timing and amount of rain and irrigation. They found that $\mathrm{ERD}_{\max }$ varied significantly from season to season, reporting values of 235 $\mathrm{cm}$ during one season and only $132 \mathrm{~cm}$ for the next season. This is quite a large difference that could have a significant impact on irrigation management. They also found that the depth of extraction increased linearly with days after emergence (DAE), but rather than considering a lag period, they assumed a minimum depth of extraction of $20 \mathrm{~cm}$ at emergence. They reported rates of increase in the depth of extraction of $3.0 \mathrm{~cm} \mathrm{day}^{-1}$ from emergence to $33 \mathrm{DAE}$ and 2.5 
$\mathrm{cm} \cdot$ day $^{-1}$ from 34 to $61 \mathrm{DAE}$ in one season and $1.8 \mathrm{~cm} \cdot \mathrm{day}^{-1}$ from emergence to $48 \mathrm{DAE}$ the following season.

From investigations of soil water extraction from cotton planted in different row configurations, [6] found that soil water extraction occurred to at least 125 $\mathrm{cm}$. For cotton planted on a solid (non-skip) row configuration, they found that the average rate of increase of the depth of extraction varied slightly with soil type. They reported average rates of $2.1,2.2$, and $2.4 \mathrm{~cm} \cdot \mathrm{day}^{-1}$ for three heavy soil types for the 1997-98 cotton season. For the same three soil types, they found the lag period to be $37.7,32.7$, and 37.5 days (after sowing). However, the next season (in 1998-99) they found that the depth of extraction increased at a rate of only $1.7 \mathrm{~cm} \cdot \mathrm{day}^{-1}$, with a lag period of 39.7 days. The lag periods obtained by [6] were considerably higher than the 23.5 days obtained in this study. Differences could be due to the fact that their study was conducted under dryland conditions.

\subsection{Seasonal Water Extraction from Each Soil Depth}

The fraction of cumulative EnvironSCAN ETc as a function of DAS for each depth and treatment is shown in Figure 11. It shows that, as expected, most of the water was extracted from shallow depths early in the season and the proportion of water extracted from each depth became more evenly distributed as the season progressed due to root growth. The distribution of water extraction from the different soil depths also changes in response to water availability. The least water present in a soil layer, the most extraction is likely to occur, if roots are present.

The fraction of seasonal soil water extraction as a function of depth of extraction for each treatment are summarised in Figure 12. It shows that for all treatments, the fraction of seasonal soil water extraction tended to decrease with depth from an average of about 0.20 (20\%) for the top $25 \mathrm{~cm}$ to about 0.05 (5\%) at a depth of $60 \mathrm{~cm}$. Each depth of more than $60 \mathrm{~cm}$ accounted for less than 0.05 (5\%) of the seasonal water extraction. The relationship in Figure 12 can be described by the following equation $\left(\mathrm{R}^{2}=0.91\right)$ :

$$
\text { FSWE }=3.147582 e^{-1}-7.327073 e^{-3} D+6.070688 e^{-5} D^{2}-1.709402 e^{-7} D^{3}
$$

where, $F S W E=$ fraction of seasonal water extraction, and $D=$ depth of extraction $(\mathrm{cm})$.

The cumulative fraction of seasonal soil water extraction as a function of depth of extraction is shown in Figure 13. The relationship in Figure 13 can be described by the following equation $\left(R^{2}=0.97\right)$ :

$$
C F S W E=6.471062 e^{-2}+2.188146 e^{-2} D-1.847685 e^{-4} D^{2}+5.382206 e^{-7} D^{3}(10)
$$

where, CFSWE = cumulative fraction of seasonal water extraction, and $D=$ depth of extraction $(\mathrm{cm})$.

Figure 13 shows that for all irrigation treatments, approximated $25 \%$ of the total seasonal water extraction came from the top $10 \mathrm{~cm}, 50 \%$ from the top 25 


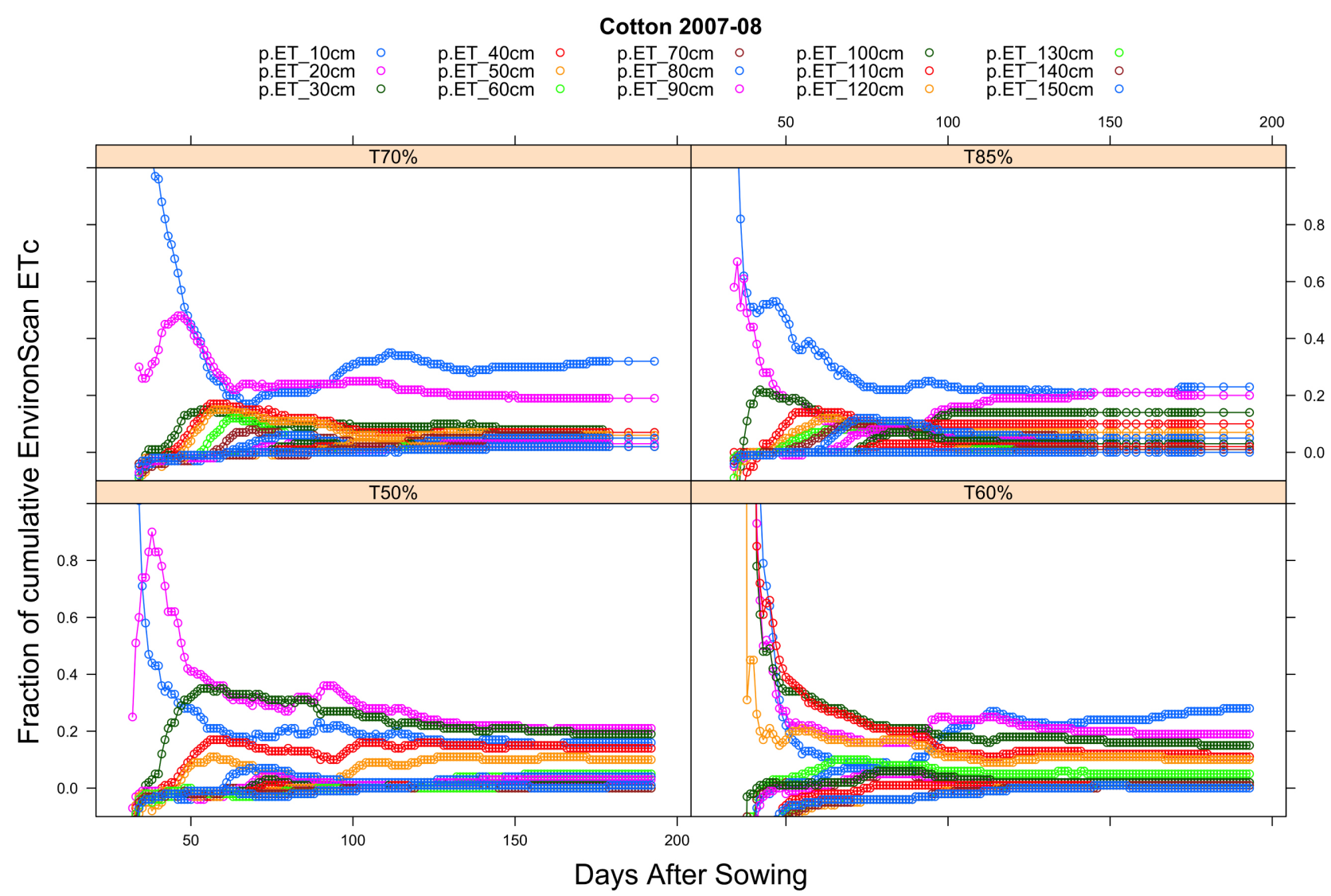

Figure 11. Daily fraction of cumulative EnvironSCAN ETc by soil depth measured with EnviroSCAN ${ }^{\circ}$ Sol $o$ as a function of days after sowing for cotton grown under four irrigation treatments (T50\%, T60\%, T70\% and T85\%) at Kingsthorpe during 2007-08. p.ET_10 cm, p.ET_20 cm, p.ET_20 cm are the fraction of cumulative ETc measured at 10, 20, and $30 \mathrm{~cm}$ depth, respectively.

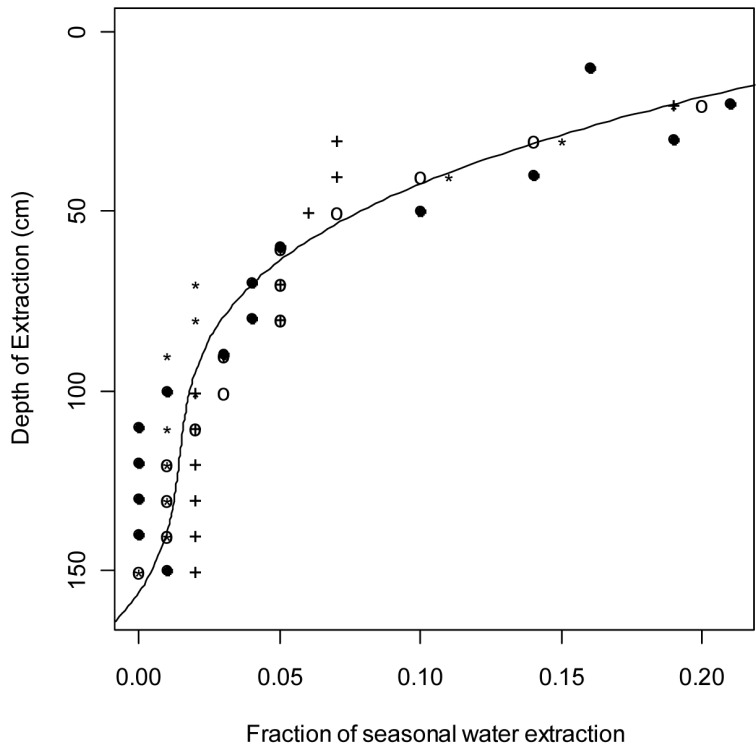

Figure 12. Fraction of seasonal water extraction as a function of depth of extraction measured with EnviroSCAN ${ }^{\circ}$ probes for cotton grown under four irrigation treatments $(\mathrm{T} 50 \%=$ "O", $\mathrm{T} 60 \%=$ " $\bigcirc ”, \mathrm{~T} 70 \%=$ “*”, and $\mathrm{T} 85 \%=$ " + ”) at Kingsthorpe during 2007-08. 


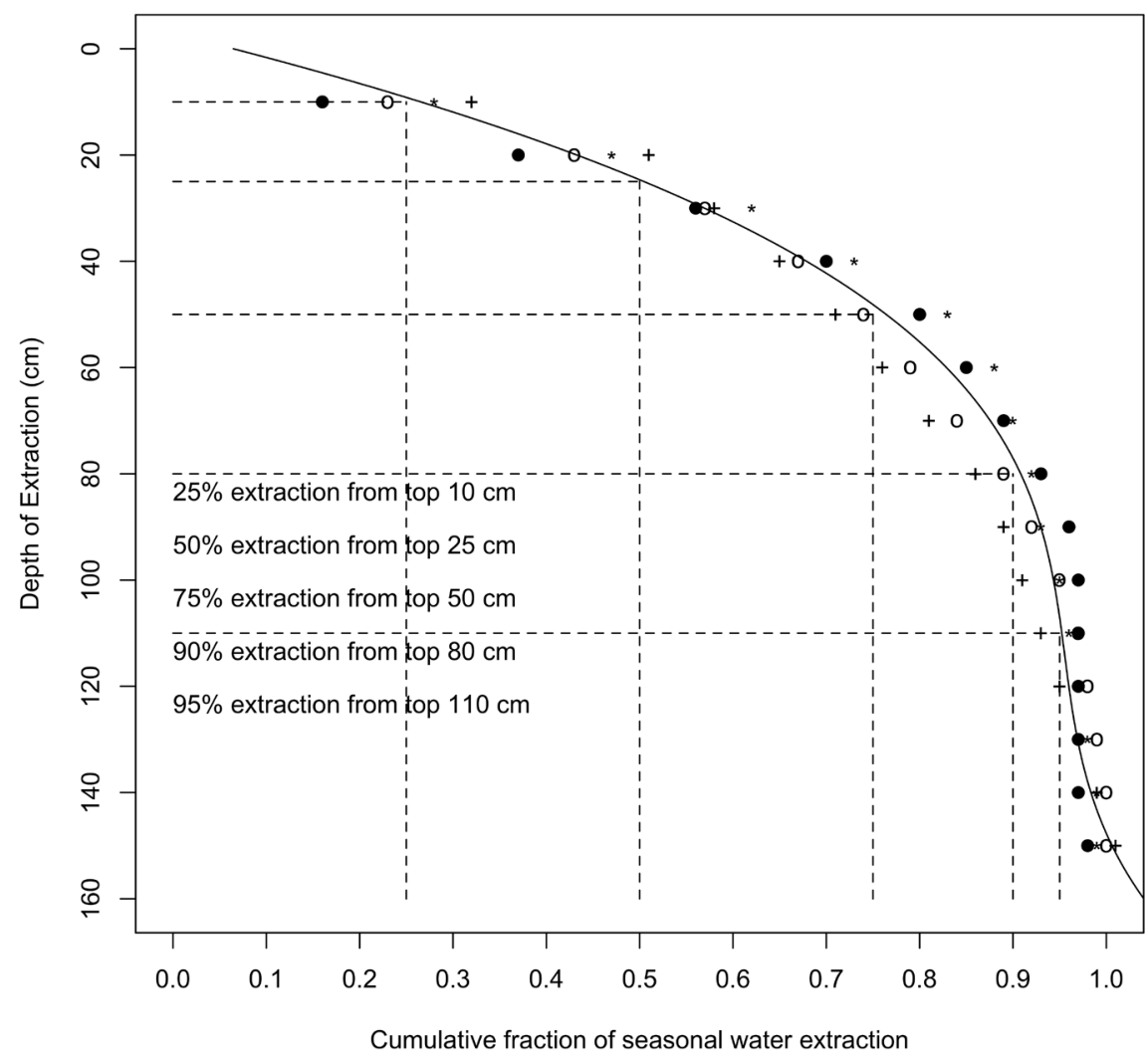

Figure 13. Cumulative fraction of seasonal soil water extraction as a function of depth of extraction measured with EnviroSCAN ${ }^{\circ}$ probes for cotton grown under four irrigation treatments $(\mathrm{T} 50 \%=$ "O”, $\mathrm{T} 60 \%=$ " $\bigcirc ", \mathrm{~T} 70 \%=$ “*”, and $\mathrm{T} 85 \%=$ "+”) at Kingsthorpe during 2007-08.

$\mathrm{cm}, 75 \%$ from the top $50 \mathrm{~cm}, 90 \%$ from the top $80 \mathrm{~cm}$, and $95 \%$ from the top 110 $\mathrm{cm}$. Low extraction from deeper depths could be due to a combination of low root density, lower water availability, and insufficient time between the arrival of the extraction front and crop maturity, especially considering that by the time the extraction front reaches the lower depths, the crop water demand (evapotranspiration) had already started to decrease significantly.

Similarly, Figure 14 shows that taking the maximum root zone depth as 150 $\mathrm{cm}$ and dividing the root zone into quarters, $65 \%$ of the seasonal water extraction came from the top $25 \%$ of the crop root zone, $89 \%$ from the top $50 \%$, and $95 \%$ for the top $75 \%$. The bottom quarter only accounted for $5 \%$ of the seasonal water extraction. Therefore, the top quarter extracted $65 \%$; the second quarter, $24 \%$; the third quarter, $6 \%$ and; the bottom quarter, $5 \%$. These results are quite different from the 4:3:2:1 rule of thumb used to estimate the water absorption over the course of a season. This rule of thumb suggests of the seasonal crop water extraction, $40 \%$ comes from the top quarter layer of the crop root zone, 30\% from the second quarter, $20 \%$ from the third quarter and, $10 \%$ from the bottom quarter of the crop root zone [17]. The much higher extraction from the top quarter observed in this study compared to the 4:3:2:1 rule of thumb was likely due to the fact that with the sprinkler irrigation system used in this study, small 


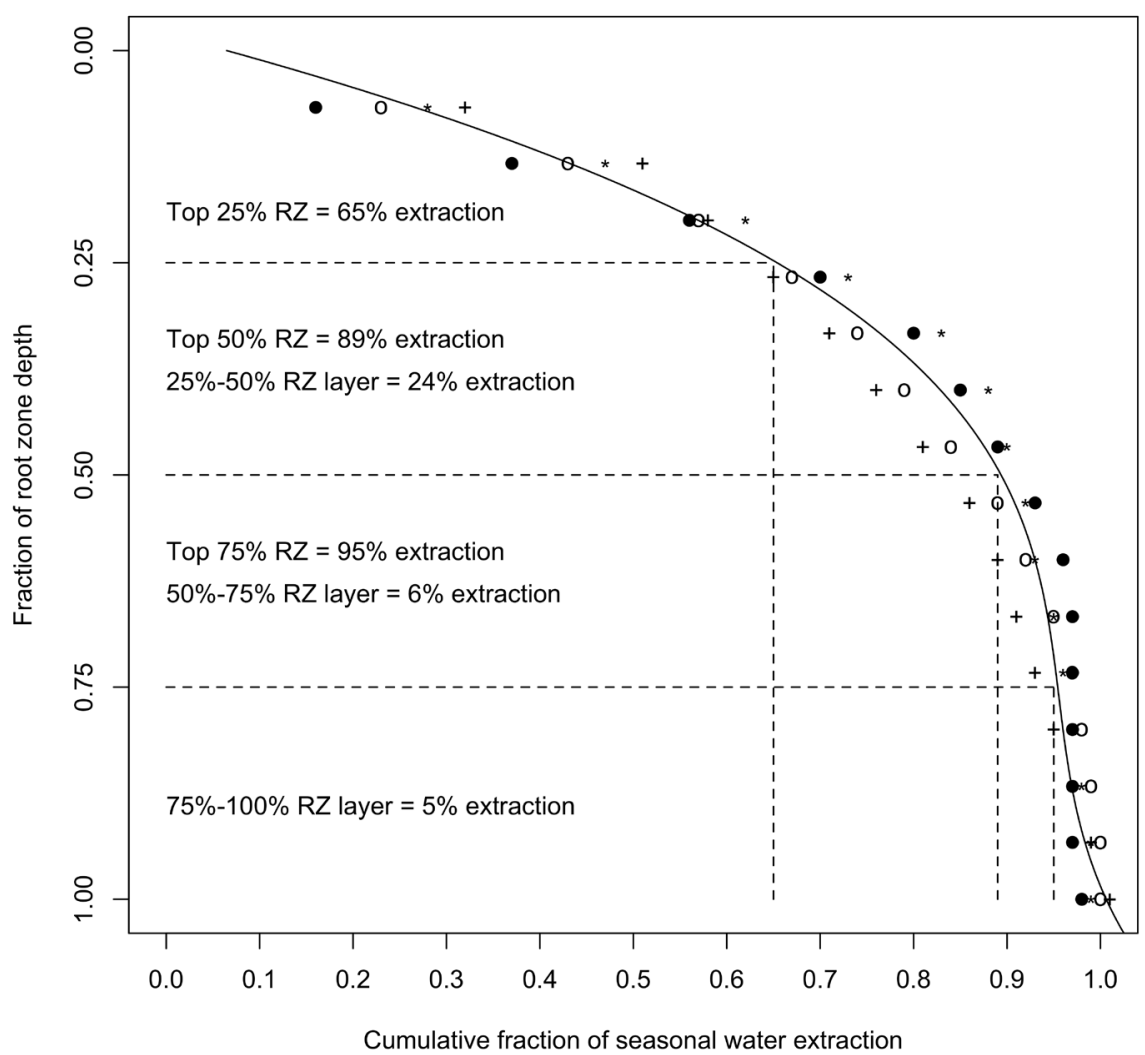

Figure 14. Cumulative fraction of seasonal soil water extraction as a function of fraction of root zone depth measured with EnviroSCAN ${ }^{\circ}$ probes for cotton grown under four irrigation treatments $(\mathrm{T} 50 \%=$ "○", $\mathrm{T} 60 \%=$ " $\bigcirc$ ", $\mathrm{T} 70 \%=$ “*”, and $\mathrm{T} 85 \%=$ "+”) at Kingsthorpe during 2007-08. RZ = root zone. The maximum root zone depth was 150 $\mathrm{cm}$.

irrigation depths were applied rather than refilling the soil profile during each irrigation event. Therefore, the small irrigation depths only tended to wet the top quarter of the crop root zone.

Our findings are consistent with those recently reported by [18] for cotton, who found negligible change in soil water content in layers below $120-135 \mathrm{~cm}$ depth, indicating that the top $120 \mathrm{~cm}$ soil depth accounted for over $95 \%$ of the root water extraction. However, in our study, $95 \%$ of the seasonal soil water extraction occurred from an even shallower depth of about $110 \mathrm{~cm}$.

These results then suggest that irrigation for cotton should be targeted at wetting only the top $80 \mathrm{~cm}$ of the soil profile during each irrigation event, which accounted for $90 \%$ of the seasonal water extraction. This means reducing irrigation depths during each irrigation event and increasing irrigation frequently. Currently, the common practice in the Australian cotton industry is to allow relatively high soil water depletions and then applying furrow irrigation to refill the profile to depths far exceeding $80 \mathrm{~cm}$. This common practice is likely to produce crop stress, resulting in lower yields, and water losses by deep drainage and runoff.

Many growers, however, believe that no deep percolation losses occur in the 
heavy soils common in Australia due to low infiltration rates. However, recent studies have shown that significant losses do in fact occur. For example, [19] evaluated surface irrigation events in cotton fields in Queensland and found that at the field level, irrigation application efficiencies varied widely from 17\% $100 \%$ with an average of $48 \%$. They also found that deep percolation losses averaged $42.5 \mathrm{~mm}$ per irrigation event, representing an annual loss of up to 2.5 $\mathrm{ML} / \mathrm{ha}(250 \mathrm{~mm})$. Also, [20] found that for furrow-irrigated cotton fields in Australia, annual deep drainage rates of $1-2 \mathrm{ML} / \mathrm{ha}(100-200 \mathrm{~mm})$ were typical, and that values ranging from 0.03 to $9 \mathrm{ML} / \mathrm{ha}$ ( 3 to $900 \mathrm{~mm}$ ) had been observed.

\section{Conclusions}

We found that the depth of soil water extraction for cotton increased linearly with DAS, CGDD, and plant canopy height, from 32 DAS to 100 DAS, until a maximum depth of extraction was reached. The depth of extraction increased almost linearly with DAS and CGDD at a rate of $1.89 \mathrm{~cm} \cdot \mathrm{day}^{-1}$ and $0.165 \mathrm{~cm}$ per ${ }^{\circ} \mathrm{C}$ day, respectively. The depth of extraction also increased almost linearly at a rate of 2.36 times the crop canopy height during the same period. In this study, however, we were not able to assess the nature of the increase in depth of extraction prior to $32 \mathrm{DAS}$, before the depth of extraction reached $10 \mathrm{~cm}$. However, the depth of extraction did not start to increase at the linear rate starting at sowing or crop emergence, but there was a lag period that we estimated as 23.5 days. Since depth of extraction is difficult to evaluate in the field, the good linear relationship between depth of extraction and canopy height obtained in this study can be used to assist in irrigation management.

We also found that about $90 \%$ of the seasonal water extraction by the cotton crop took place from the top $80 \mathrm{~cm}$ soil depth, and depths below $110 \mathrm{~cm}$ accounted for only $5 \%$ of the seasonal water extraction. The practical significance of these findings is that cotton producers should manage irrigation aimed at maintaining adequate soil water content in the top $80 \mathrm{~cm}$ of the soil profile by applying frequent and light irrigations. This contrasts with the current common practice in the Australian cotton industry of applying large irrigation depths to refill the soil profile during each irrigation event, which could lead to large water losses. The information obtained in this study is also valuable for modelling cotton soil water extraction pattern and water use.

\section{Acknowledgements}

The authors would like to acknowledge the contribution provided by the Department of Agriculture and Fisheries, the Cotton Communities CRC, and the Cotton Research \& Development Corporation. Technical Contribution No. 6590 of the Clemson University Experiment Station. This material is based upon work supported by NIFA/USDA, under project number SC-1700540. Commercial names were included for the benefit of the reader and did not imply endorse- 
ment by the authors or their organizations.

\section{References}

[1] Ali, M.H. and Talukder, M.S.U. (2008) Increasing Water Productivity in Crop Production-A Synthesis. Agricultural Water Management, 95, 1201-1213.

[2] Raes, D., Steduto, P., Hsiao, T.C. and Fereres, E. (2009) Chapter 1. AquaCrop-The FAO Crop Model to Simulate Yield Response to Water. Food and Agriculture Organization of the United Nations, Rome.

[3] Monteith, J.L. and Greenwood, D.J. (1986) How Do Crops Manipulate Water Supply and Demand? Philosophical Transactions of the Royal Society of London. Series A, Mathematical and Physical Sciences, 316, 245-259. https://doi.org/10.1098/rsta.1986.0007

[4] Passioura, J.B. (1983) Roots and Drought Resistance. Agricultural Water Management, 7, 265-280.

[5] Robertson, M.J., Fukai, S., Ludlow, M.M. and Hammer, G.L. (1993) Water Extraction by Grain Sorghum in a Sub-Humid Environment. I. Analysis of the Water Extraction Pattern. Field Crops Research, 33, 81-97.

[6] Goyne, P.J. and Hare, J. (1999) Improved Understanding of Cotton Water Use for Better Management in Water Limited Environments: Annual Progress Report. Queensland Department of Primary Industries and Fisheries/Farming Systems Institute, Hermitage, 77.

[7] Goyne, P.J. and Hare, J.M. (1999) Soil Water Extraction Dymamics of Dryland Cotton in Various Row Configurations. Proceedings of the Beltwide Cotton Conference, National Cotton Council, 1280-1282.

[8] Keating, B.A., Carberry, P.S., Hammer, G.L., Probert, M.E., Robertson, M.J., Holzworth, D., Huth, N.I., Hargreaves, J.N.G., Meinke, H., Hochman, Z., McLean, G., Verburg, K., Snow, V., Dimes, J.P., Silburn, M., Wang, E., Brown, S., Bristow, K.L., Asseng, S., Chapman, S., McCown, R.L., Freebairn, D.M. and Smith, C.J. (2003) An Overview of APSIM, a Model Designed for Farming Systems Simulation. European Journal of Agronomy, 18, 267-288.

[9] Cotton Seed Distributors (2007) Variety Guide. Cotton Seed Distributors, Toowoomba, 1-18.

[10] Sentek Sensor Technologies (2001) Calibration of Sentek Pty Ltd Soil Moisture Sensors. Srepney.

[11] Robertson, M.J., Fukai, S., Ludlow, M.M. and Hammer, G.L. (1993) Water Extraction by Grain Sorghum in a Sub-Humid Environment. II. Extraction in Relation to Root Growth. Field Crops Research, 33, 99-112.

[12] Lacape, M.J., Wery, J. and Annerose, D.J.M. (1998) Relationships between Plant and Soil Water Status in Five Field-Grown Cotton (Gossypium hirsutum L.) Cultivars. Field Crops Research, 57, 29-43.

[13] Silim, S.N. and Saxena, M.C. (1993) Adaptation of Spring Sown Chickpea to the Maditerranean Basin: I. Response to Moisture Supply. Field Crops Research, 21, 121-136.

[14] McMaster, G.S. and Wilhelm, W.W. (1997) Growing Degree-Days: One Equation, Two Interpretations. Agricultural and Forest Meteorology, 87, 291-300.

[15] Allen, R.G., Pereira, L.S., Raes, D. and Smith, M. (1998) Crop Evapotranspiration-Guidelines for Computing Crop Water Requirements-FAO Irrigation and Drainage Paper 56. FAO, Rome. 
[16] R Development Core Team (2011) R: A Language and Environment for Statistical Computing. R Foundation for Statistical Computing, Vienna.

[17] Scherer, T.F., Kranz, W.L., Pfost, D., Werner, H., Wright, J.A. and Yonts, C.D. (1999) Sprinkler Irrigation Systems. MidWest Plan Service, Ames.

[18] Oweis, T.Y., Farahani, H.J. and Hachum, A.Y. (2011) Evapotranspiration and Water Use of Full and Deficit Irrigated Cotton in the Mediterranean Environment in Northern Syria. Agricultural Water Management, 98, 1239-1248.

[19] Smith, R.J., Raine, S.R. and Minkevich, J. (2005) Irrigation Application Efficiency and Deep Drainage Potential under Surface Irrigated Cotton. Agricultural Water Management, 71, 117-130.

[20] Silburn, M. and Montgomery, J. (2004) Deep Drainage under Irrigated Cotton in Australia: A Review. WATERpak: A Guide for Irrigation Management in Cotton. Australian Government Cotton Research and Development Corporation and Australian Cotton Cooperative Research Centre, Narrabri, 29-40. 